\title{
Fixed Assets and Inventory Analysis with Reference to Ford India Private Limited
}

\author{
R. Ramamoorthy, Indumathi, Velvizhi R
}

\begin{abstract}
Fixed Assets are the benefits held with the goal of being utilized on persistent reason for thepurpose of delivering or giving products or benefits and are not held for resale in the typical course ofbusiness. Valuation of fixed resources is critical to have reasonable proportion of benefit or misfortune and financialposition of the worry and is intended to be for more years. [1],[3],[5]
\end{abstract}

Extent assessment is the connection of subtleties in the spending outlines of a business. Extent assessment is used to survey different issues with a component, for instance, its liquidity, profitability of exercises, and advantage. It is profitable particularly to process the Trend line. This assessment in like manner contains design examination. [2 ], [ 4],[6]

Stock proportionality is the goal of intrigue driven stock organization. The fundamental perfect outcome is to have a comparative number of long stretches of stock accessible over all things with the objective that the period of miss the mark on all things would be synchronous. The discretionary goal of stock proportionality is stock minimization. [7],[9],[11]

Through coordinating exact interest estimating with stock administration, replenishmentinventories can be planned to arrive in the nick of time to renew the item bound to runout first, while simultaneously offsetting the stock supply of all items to make their inventories progressively corresponding, and in this way closer to accomplishing the essential objective.

The EOQ done in this venture demonstrates the degree of inventories that is utilized for creation and the estimation of the inventories. The $A B C$ approach expresses that, when checking on stock, an organization should rate things from $A$ to $C$, putting together its evaluations depending with respect to specific principles. This is additionally clarified in the Data Analysis area of this task. [19],[21],[23]

Keywords : trademarks,copyright,firm

\section{INTRODUCTION}

Fixed asset is a whole deal some segment of a property that the association has and utilizes in the age of its pay and isn't anticipated that would be eaten up or used into cash in coming years. It is a thing with a supportive life more essential than one enumerating period, and which outperforms a substance's base capitalization limit. These are

Revised Manuscript Received on July 22, 2019.

R.Ramamoorthy, Department of MBA, Bharath Institute of Higher Education and Research, Tamilnadu, India. Email: ramamoorthy0071@gmail.com

Indumathi, Department of MBA, Bharath Institute of Higher Education and Research, Tamilnadu, India. Email: indumba@gmail.com

Velvizhi R, , Department of CSE, Bharath Institute of Higher Education and Research, Tamilnadu, India. Email: velvizhisp@gmail.com furthermore known asCapital assets that are those points of interest picked up to carry on the matter of an association with a genuine presence outperforming one year. Models include: land, structures, vehicles, contraptions, equipment, PC hardware, gear, etc. The term 'Fixed Asset' is usually used to portray significant fixed assets. This suggests they have a physical substance not in the least like insignificant assets which have no physical nearness, for instance, copyright and trademarks. [8],[ 10] ,[12]

Theorists and credit supervisors use these reports to choose an association's budgetary prosperity and to pick whether to buy shares in or advance money to the business. Since an association may use an extent of recognized systems for narrative, downgrading, and disposing of its points of interest, specialists need to mull over the notes on the organization's financialstatements to find how the numbers were settled.

Capital Intensive: Businesses that have a high proportion of capital expenses to work expenses are known as that may be, they require an enormous budgetary interest in capital resources for produce merchandise or administrations. Instances of capital serious enterprises incorporate mining, cultivating, carriers, oil and gas, angling, and so forth. [13], [15], [ 17]

Fixed resources are especially critical to capitalintensive enterprises, for example, producing, that require huge interests in PP\&E. At the point when a business is detailing relentlessly negative net money streams for the buy of fixed resources, this could be a solid pointer that the firm is in development mode. [14],[ 16], [18]

Fixed resources are typically expected to be utilized for more than one bookkeeping period which is the reason they are a piece of Non-Current Assets of the substance. Financial advantages from fixed resources are in this manner determined in the long haul. [20],[22], [24]

\section{OBJECTIVES}

\section{A. Primary Objective}

To study on the overall fixed assets and inventory analyses of Ford India Pvt Ltd.

B. Secondary Objectives:

- To comprehend the different monetary elements of the organization.

- To study on the fixed resources.

- To know the organization's stock administration process. 
- To comprehend the significance of assessing the organization's fixed resources.

- To dissect the stock and cost control proportions of the organization.

\section{METHODS OF DATA COLLECTION}

\section{A. PRIMARY DATA COLLECTION}

This investigation depends on the essential information. Essential information is the subtleties that is gathered physically, here in the money division of CVEP (Ford) the procedure of confirmation is finished. We physically proceed to check whether the inventories are appropriately handled for creation. Any deformities, flaws, missing inventories will be noted for further explanation, after which it will be refreshed methodicallly. This process is done mainly to:

To guarantee that the supply of crude material and completed cooperative attitude stay nonstop so procedure isn't going and requests of clients are properly met. [25],[27],[29]

\section{B. SECONDARY DATA COLLECTION}

Optional information is gathered by the accessibility, it incorporates Inventory Data, Balance Sheet, Annual Reports, Books and Journals. What's more, some are gathered from the organization site. [26],[28],[30]

\section{SAMPLING METHOD}

This examination depends on Convenience inspecting strategy under the Non likelihood testing procedure. In this technique the information is gathered straightforwardly relying upon the accessibility of information that incorporates archives and records, for example, analyzing existing information as databases, money related manual, meeting minutes, reports, logs, budgetary records, pamphlets, and so on. [31],[33],[32]

\section{DATA ANALYSIS AND INTERPRETATION}

Table:1 RAW MATERIALS

\begin{tabular}{|l|l|}
\hline YEAR & $\begin{array}{l}\text { AMOUNT OF RAW MATERIAL } \\
\text { (in millions) }\end{array}$ \\
\hline 2013 & 3613 \\
\hline 2014 & 3822 \\
\hline 2015 & 4005 \\
\hline 2016 & 3843 \\
\hline 2017 & 4397 \\
\hline
\end{tabular}

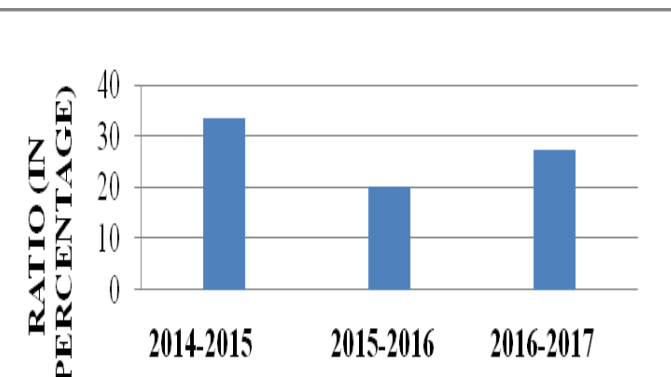

Fig:1 Raw material

FINISHED GOODS:

These are the carrying amount as of the balance sheet date of merchandise or goods held by the company that are readily available for sale.

Table:2 Finished Goods

\begin{tabular}{|l|l|}
\hline YEAR & $\begin{array}{l}\text { AMOUNT OF FINISHED GOODS } \\
\text { (in millions) }\end{array}$ \\
\hline 2013 & 5058 \\
\hline 2014 & 5022 \\
\hline 2015 & 5254 \\
\hline 2016 & 5943 \\
\hline 2017 & 6779 \\
\hline
\end{tabular}

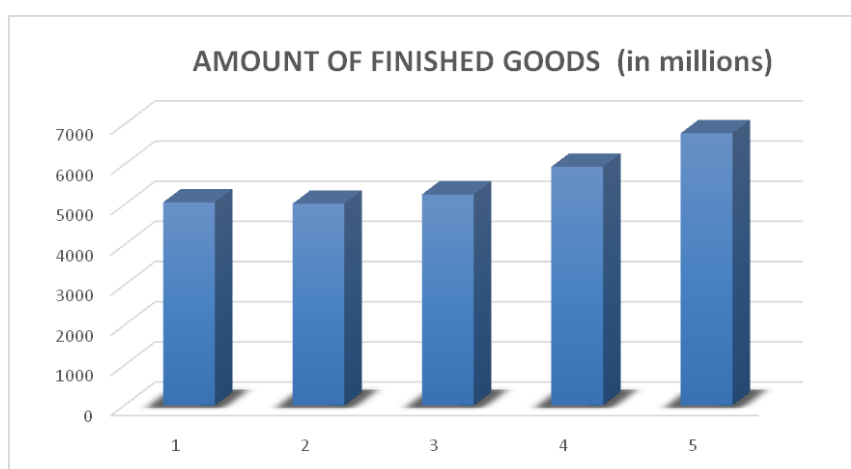

Fig:2 Finished goods

Table :3 Ratio Analysis

\begin{tabular}{|l|l|l|l|}
\hline YEAR & NET FIXED ASSET & NET WORTH & RATI0 \% \\
\hline $2016-17$ & 228928 & 29283 & 7.81 \\
\hline $2015-16$ & 216932 & 28751 & 7.56 \\
\hline $2014-15$ & 210546 & 28590 & 7.36 \\
\hline $2013-14$ & 204075 & 27685 & 7.37 \\
\hline
\end{tabular}

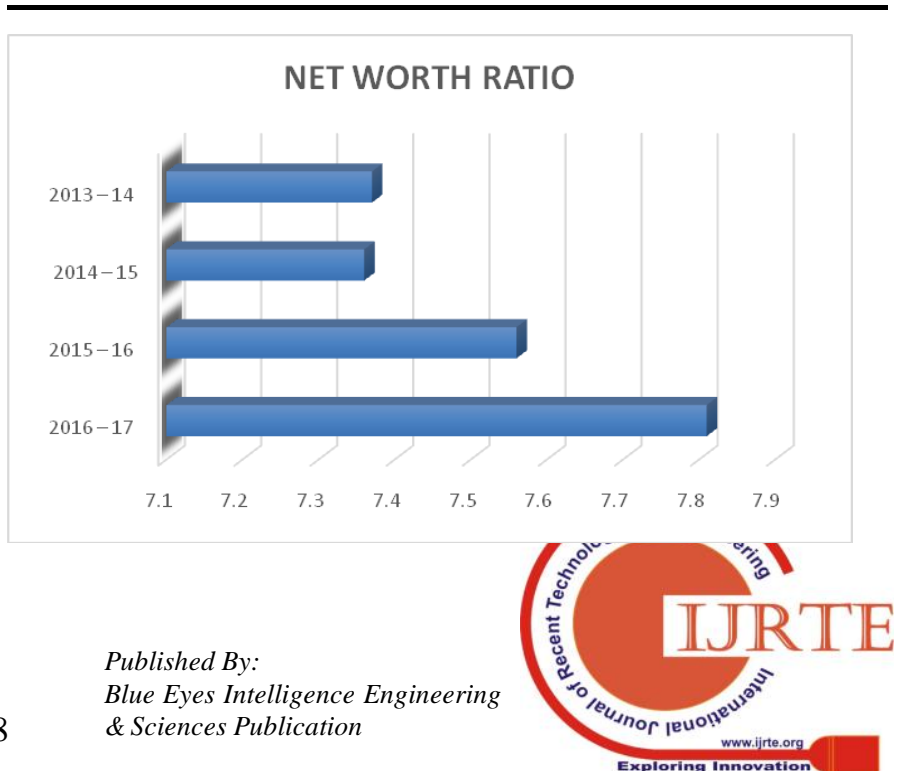


Fig:3 Net Worth Ratio

Table:4 Fixed Asset Ratio

\begin{tabular}{|l|l|l|l|}
\hline YEAR & NET FIXED ASSET & CAPTIAL EIIPLOYED & RATIO\% \\
\hline $2016-17$ & 228928 & 147670 & 1.55 \\
\hline $2015-16$ & 216932 & 142589 & 1.52 \\
\hline $2014-15$ & 210932 & 142510 & 1.48 \\
\hline $2013-14$ & 204075 & 142085 & 1.44 \\
\hline
\end{tabular}

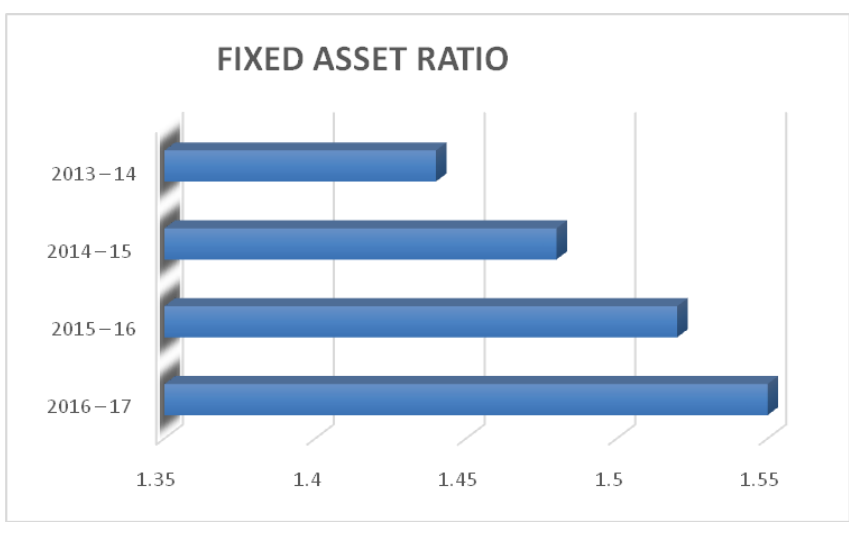

Fig:4 Fixed Asset Ratio

Table :5 RETURN ON FIXED ASSETS (ROA)

\begin{tabular}{|l|l|l|l|}
\hline YEAR & PROFIT AFTER TAX & TOTAL ASSETS & RATI0\% \\
\hline $2016-17$ & 4607 & 237951 & 0.019 \\
\hline $2015-16$ & 7371 & 224925 & 0.032 \\
\hline $2014-15$ & 1230 & 217931 & 5.6 \\
\hline $2013-14$ & 2451 & 211017 & 0.011 \\
\hline
\end{tabular}

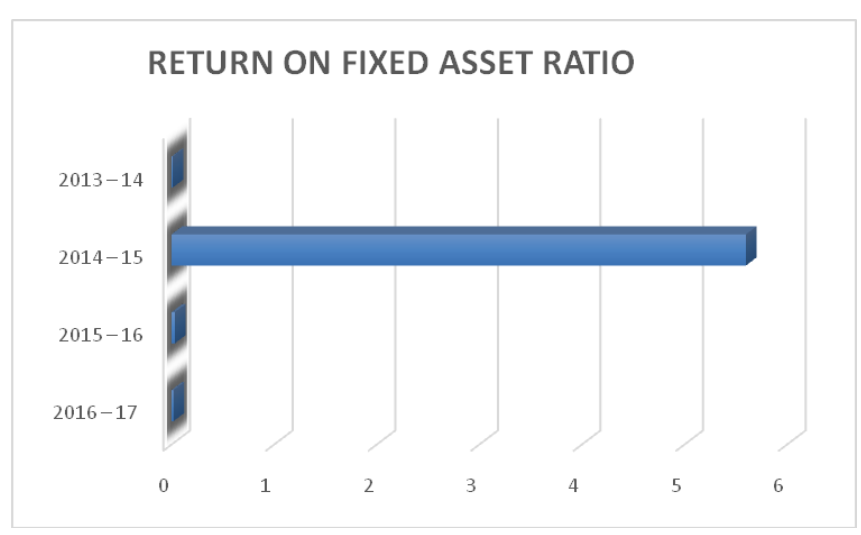

Fig:5 RETURN ON FIXED ASSETS (ROA)
Table:7

\begin{tabular}{|l|l|}
\hline PARTICULARS \\
\hline Quantity & $1,765,100 \mathrm{~kg}$ \\
\hline Ordening cost per order & $1,86,000$ \\
\hline Purchase price Per unit & 152 \\
\hline Canying cost & $10 \%$ \\
\hline
\end{tabular}

\section{DURING THE PERIOD: DECEMBER 2012 - 2013}

The company requires the below given amount of raw materials of aluminium coils for the production of around 12,000 cars per month.

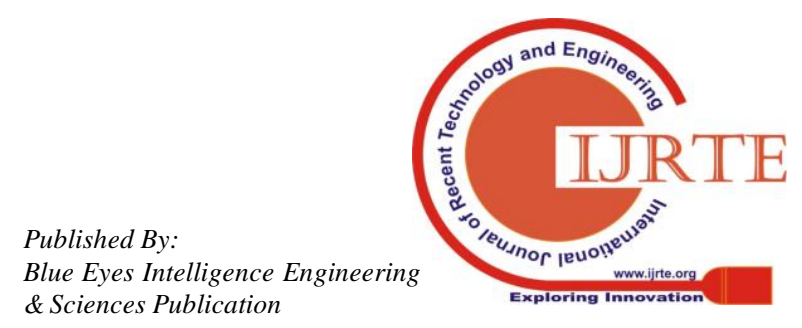




\section{V.RESULTS}

- There is an expanding development in the benefits of the organization for as long as five years.

- The EOQ determined is proposing that the organization ought to acquire its stock prerequisites by setting orders habitually to its providers.

- From the EOQ, the all out yearly expense of the organization during the years 2013 - 14 and 2015 16 where practically same while, the year $2014-15$ demonstrated a climb.

- The $\mathrm{ABC}$ investigation demonstrates the ordered estimations of the things, from which the inventories can be overseen well.

- The most reduced utilization esteem "C" has the rate estimation of $1 \%$.

- The organization has many sub divisions in the Department of "Money" that gives more proficiency and profitability.

- Regular cycle checks are finished by the MP\&L group that are additionally confirmed by account office.

- Inventories are appropriately checked at specific timespans.

- Internal control and review goes about as a different division.

- The Inventory reviews and checks are done physically at the regarded stages.

- Scrap is being checked routinely and the procedure is finished in each 31 days.

\section{DISCUSSION}

Maintaining exceptional resource data by monitoring their area utilization caretaker, support and protection could build their profitability all the more proficiently.

- Group fixed resource must be under $\$ 100000$, of which life ought to be more prominent than 1 year.

- Low cost fixed resource might be gotten mass.

- Special devices for sellers are really claimed by Ford that are at merchant's area are not confirmed subsequently periodical confirmation should be possible that will profit in holding resources.

- Retention of benefit confirmation are held under records at any rate for a long time. Every year the records are refreshed by the specific record's time span of usability.
The Company's generally speaking fixed resource the executives of the organization has all the earmarks of being more than attractive. It is achieving the objectives towards progress. The money office plays out the accompanying capacities to keep fixed resources very much kept up.

When an advantage is bought and recorded, it is followed. All the fixed resources are for all time taggedwith a fixed resource label that contains a sequential number. The number ought to compare to a log book or the fixed resource module (the auxiliary record) of the bookkeeping framework.

Each fixed resource's physical area is archived and any moves inside or outside the office are recorded. Any deals, new acquisitions, or rescues are likewise be recorded to guarantee repaired resource stock is to date.

The financial request amount and the reorder point, upgraded the request amount for every item when a request is put, diminishing the organization's item stock out issue Inventory the executives must be accomplished for keeping exact records of merchandise that are prepared for creation. The organization gathers the cycle check data and procedure it methodicallly to look after records. To know the genuine inventories that are accessible for creation. Stock administration is significant for holding cost down, while meeting guideline. Free market activity is a sensitive parity and this stock administration plans to guarantee that the parity is undisturbed.

The EOQ model guides the organization in anticipating all the more precisely as indicated by every item and their interest practices. Alongside the anticipating model, the financial request amount enables the organization to enhance each request and diminish the absolute expense. The ABC examination demonstrates the rate estimation of the materials that can be classified by the interest and the expense of the things. Thus, the organization would guarantee enough inventories are accessible for creation.

\section{REFERENCES}

1. G BharthVajan R., Ramachandran S.,Psychographic dimensions of training,2016,International Journal of Pharmacy and Technology,V-8,I-4,P-23727-23729

2. Balakrishnan P., Bharthvajan R.,A study on human resource planning in hospitals in Chennai City,2014,International Journal of Applied Engineering Research,V-9,I-22,P-7503-7507

3. Priyadarsini P., Bharthvajan R.,Role of emotional intelligence training programme in reducing the stress of the nurses,2014,International Journal of Applied Engineering Research,V-9,I-22,P-7411-7421

4. Kerinab Beenu G., Bharthvajan R.,Empirical analysis on the cosmetic buying behavior of young women in South India,2014,International Journal of Applied Engineering Research,V-9,I-22,P-7361-7366

5. Balakrishnan P., Bharthvajan R.,Whistling in the wind,2014,International Journal of Applied Engineering Research,V-9,I-22,P-7586-7593

6. Krishnan B., Peter M.,Health hazards of Indian Bpo employee-an alarming issue,2014,International Journal of Applied Engineering Research,V-9,I-22,P-7336-7341

7. Kerinab Beenu G.H., Peter M.,Role of insurance in economic development,2014,International Journal of Applied Engineering Research,V-9,I-22,P-7532-7539

8. Balakrishnan P., Peter M., Priyadarsini P.,Efficiency of safety measures for wellbeing of employees in manufacturing industry,2014,International Journal of Applied Engineering Research,V-9,I-22,P-7376-7382 
9. Anbarasi M., Praveen Kumar S.,Online sales promotions of herbal products and its effectiveness towards tanisha.com,2019,Indian Journal of Public Health Research and Development,V-10,I-1,P-195-200

10. Anbarasi M., Praveen Kumar S.,Various online marketing and promotions strategies to improve the validation towards the organic products in the pharmaceutical sectors,2019,Indian Journal of Public Health Research and Development,V-10,I-1,P-263-269

11. Loganathan R., Praveen Kumar S.,Grievance handling a key factor for solving issues of employees in an organization,2014,International Journal of Applied Engineering Research,V-9,I-22,P-7483-7491

12. Loganathan R., Praveen Kumar S.,Study on preference of private label brands in super and Hypermarkets,2014,International Journal of Applied Engineering Research,V-9,I-22,P-7327-7335

13. Smitha M., Praveen Kumar S.,Understanding stress and its managementamong the nurses in Chennai city,2014,International Journal of Applied Engineering Research,V-9,I-22,P-7560-7565

14. Kerinab Beenu G.H., Praveen Kumar S.,A study on the investment behavior of Chennai investors in mutual fund schemes,2014,International Journal of Applied Engineering Research,V-9,I-22,P-7520-7525

15. Loganathan R., Praveen Kumar S.,Retention strategies key for organizational productivity,2014,International Journal of Applied Engineering Research,V-9,I-22,P-7443-7447

16. Pavithra J., Ganesan M., Brindha G.,State wise analysis of microfinance sector in India,2016,International Journal of Pharmacy and Technology,V-8,I-4,P-23417-23432

17. Pavithra J., Ganesan M.,A comparative study on microfinance in India and abroad,2016,International Journal of Applied Business and Economic Research,V-14,I-8,P-5471-5476

18. Pavithra J., Ganesan M.,A study on awareness and impact of micro-financial schemes,2016,International Journal of Applied Business and Economic Research,V-14,I-8,P-5449-5460

19. Senthilmurugan P., Pavithra J.,Consumer preference towards organised retailing with reference to Big Bazaar,2014,International Journal of Applied Engineering Research,V-9,I-22,P-7469-7475

20. Senthilmurugan P., Pavithra J.,Implication of social media marketing in growing healthcare industry,2014,International Journal of Applied Engineering Research,V-9,I-22,P-7448-7456

21. Loganathan R., Pavithra J.,Consumer perception towards private label brand over other brands in super markets and hypermarkets,2014,International Journal of Applied Engineering Research,V-9,I-22,P-7355-7360

22. Kerinab Beenu G., Pavithra J.,Tradeâ€"off between liquidity and profitability in logistics industry,2014,International Journal of Applied Engineering Research,V-9,I-22,P-7398-7401

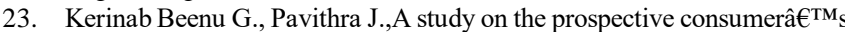
perception towards utility cars in Chennai city,2014,International Journal of Applied Engineering Research,V-9,I-22,P-7526-7531

24. Pavithra J., Dilli Babu P., Ambuli T.V.,A study on budgetary control at Maruti Service Masters, Chennai,2014,International Journal of Applied Business and Economic Research,V-12,I-2,P-151-161

25. Pavithra J., Dilli Babu P., Ambuli T.V.,A study on customer satisfaction of retro Garments Pvt Ltd, Chennai,2014,International Journal of Applied Business and Economic Research,V-12,I-2,P-381-391

26. Kerinab Beenu G.H., Pavithra J., Senthilmurugan P.,A study on the influence of promotional activities for TATA ARIA among consumers in Chennai,2014,International Journal of Applied Engineering Research,V-9,I-22,P-7572-7578

27. Vijayaragavan S.P.,An investigative expert that's general FBG sensors,International Journal of Mechanical Engineering and Technology,V-8,I-8,PP-1500-1505,Y-2017

28. Vijayaragavan S.P.,Equalization routing protocol for Wi-Fi sensor strategy,International Journal of Mechanical Engineering and Technology,V-8,I-8,PP-1662-1666,Y-2017

29. Karthik B., Kiran Kumar T.V.U., Vijayaragavan P., Bharath Kumaran E.,Design of a digital PLL using 0.35 $\hat{\mathrm{I}}^{1 / 4 \mathrm{~m}}$ CMOS technology,Middle East Journal of Scientific Research,V-18,I-12,PP-1803-1806,Y-2013

30. Kanniga E., Selvaramarathnam K., Sundararajan M.,Kandigital bike operating system,Middle - East Journal of Scientific Research, V

31. Jasmin M., Vigneshwaran T., Beulah Hemalatha S.,Design of power aware on chip embedded memory based FSM encoding in FPGA,International Journal of Applied Engineering Research,V-10,I-2,PP-4487-4496,Y-2015

32. Jasmin M.,Optimization techniques for low power VLSI circuits,Middle East Journal of Scientific Research,V-20,I-9,PP-1082-1087,Y-2014

33. Jasmin M., Vigneswaran T.,Fuzzy controller for error control of on - Chip communication,2017 International Conference on Algorithms, Methodology, Models and Applications in Emerging Technologies, ICAMMAET 2017,V-2017-January,I-,PP-1-5,Y-2017

\section{AUTHORS PROFILE}

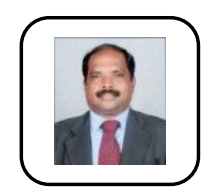

Ramamoorthy, Assistant Professor ,Department of MBA, Bharath Institute of Higher Education and Research, Tamilnadu, India

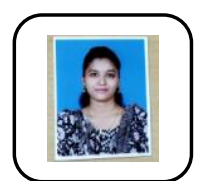

Indumathi , Student ,Department of MBA, Bharath Institute of Higher Education and Research, Tamilnadu, India

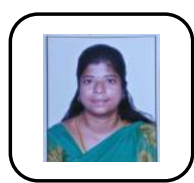

Velvizhi Assistant Professor ,Department of CSE, Bharath Institute of Higher Education and Research, Tamilnadu, India 